\title{
Peripheral insensitivity to thyroid hormones in a euthyroid girl with goitre
}

\author{
JORMA MÄENPÄÄ AND KRISTIAN LIEWENDAHL \\ Children's Hospital and Department of Clinical Chemistry, Helsinki University Central Hospital, and \\ Minerva Foundation Institute, Helsinki, Finland
}

SUMMARY A 9-year-old girl was euthyroid with a small goitre, exophthalmos, scaphocephalic skull, minor sketelal abnormalities, and raised serum thyroid hormone concentrations. Other members of the family did not have goitres and their thyroid hormone levels were normal. From age 3 years the patient was treated for Graves's disease, but after 4 years treatment was stopped because of enlargement of the goitre. Despite increased serum thyroxine (T4), free T4 (FT4), and triiodothyronine (T3), basal serum TSH, and the TSH response to thyrotropin-releasing hormone (TRH) were normal. Pituitary refractoriness was present because full suppression of the TSH response to TRH was achieved only after daily administration of $500 \mu \mathrm{g}$ thyroxine. Urinary excretion of hydroxyproline, and the activity of red cell glucose-6-phosphate dehydrogenase remained normal when excess T4 was administered, demonstrating the tissue resistance to thyroid hormones. Peripheral lymphocytes were found to have nuclear receptors for $\mathrm{T} 3$ with normal affinity, but the relatively low binding capacity indicated that the biochemical defect might be a deficiency of nuclear receptor protein. The findings in this patient differ somewhat from previously reported cases of peripheral resistance to thyroid hormones.

In recent years several euthyroid patients have been reported with end-organ insensitivity to thyroid hormones. Members of families with hereditary forms of peripheral resistance to thyroid hormones were studied by Refetoff et al.,1 Agerbaek, ${ }^{2}$ and Lamberg et al. $^{3}$ Sporadic cases of peripheral resistance syndromes have also been observed, ${ }^{4-7}$ including a case of TSH-induced hyperthyroidism caused by selective pituitary resistance to thyroid hormones. ${ }^{8}$ According to Bernal et al. ${ }^{9}$ nuclear receptors for $\mathrm{T} 3$ which normally occur were absent in lymphocytes from a patient with a severe form of hereditary peripheral resistance syndrome. Lymphocytes from 3 patients with very slight forms of hereditary peripheral resistance had nuclear receptors with normal affinities for both T3 and T4, whereas the binding capacities for both hormones were relatively low, indicating that the primary biochemical defect might be a slight deficiency of nuclear receptors. ${ }^{10}$ As isolation of circulating lymphocytes is a convenient way of obtaining intact human nucleate cells, this procedure was used to

Department of Paediatrics, Aurora Hospital, Helsinki JORMA MÄENPÄÄ, consultant paediatrician

Department of Nuclear Medicine, Helsinki University Central Hospital

KRISTIAN LIEWENDAHL, head of department
Abbreviations:

$\mathrm{K}_{\mathrm{a}}$ : $\quad$ equilibrium affinity constant of

G-6-PD: $\quad$ glucose-6-phosphate dehydro-

HOP: $\quad$ genase

LATS: long-acting thyroid stimulator

MBC: maximal binding capacity of T3

PBI: protein-bound iodine

TBG $_{\text {cap }}$ : thyroxine-binding capacity of thyroxine-binding globulin

TBPA $_{\text {cap }}$ : thyroxine-binding capacity of thyroxine-binding prealbumin

TRH: thyrotropin-releasing hormone

TSH: thyrotropin

$\triangle T$ TSH: difference between basal and maximal TSH values in TRH stimulation test

T3: tri-iodothyronine

T3RIA: tri-iodothyronine measured by radioimmunoassay

T4: thyroxine

T4CPB: thyroxine measured by competitive protein-binding assay

T4RIA: thyroxine measured by radioimmunoassay 
study thyroid hormone receptors in a girl with target organ insensitivity to thyroid hormones.

\section{Laboratory methods}

Serum protein-bound iodine (PBI) $(0 \cdot 31-0.63$ $\mu \mathrm{mol} / \mathrm{l} ; 4 \cdot 0-8 \cdot 0 \mu \mathrm{g} / 100 \mathrm{ml})$ was measured using the Auto-Analyzer Technicon-56N method. The reference interval defined as mean $\pm 2 \mathrm{SD}$ is given in parentheses. Unless stated otherwise, the reference values were obtained from healthy adults. Our experience showed these are also valid for children over 3 years of age. Serum total thyroxine (T4CPB, 50-136 nmol/1; 3.9-10.6 $\mu \mathrm{g} / 100 \mathrm{ml}$ ) and FT4 concentrations $(30-85 \mathrm{pmol} / \mathrm{l} ; 2 \cdot 3-6 \cdot 6 \mathrm{ng} / 100$ $\mathrm{ml})$ were determined as previously described. ${ }^{11}$ Since $1976 \mathrm{~T} 4$ has been measured by radioimmunoassay (T4RIA, $60-160 \mathrm{nmol} / 1 ; 4 \cdot 7-12 \cdot 4 \mu \mathrm{g} / 100 \mathrm{ml}$ ). ${ }^{21}$ The corresponding reference interval for FT4 using T4RIA is $36-107 \mathrm{pmol} / 1(2 \cdot 8-8 \cdot 3 \mathrm{ng} / 100 \mathrm{ml})$. Serum T3 $(1 \cdot 2-2 \cdot 9 \mathrm{nmol} / 1 ; 78-190 \mathrm{ng} / 100 \mathrm{ml})$ was assayed with a commercial method (T3RIA kit, Radiochemical Centre, Amersham, England). Thyroglobulin antibodies were determined by haemagglutination technique and microsomal antibodies before 1976 with complement fixation, but since 1976 a haemagglutination technique has been used. The other methods used were: TSH by radioimmunoassay (normal, 1.6-6.9 mU/1,), ${ }^{12}$ longacting thyroid stimulator with the McKenzie bioassay (LATS), ${ }^{13}$ thyroxine-binding capacity of thyroxine-binding globulin $\left(\mathrm{TBG}_{\mathrm{cap}}\right.$, normal $0 \cdot 19-0.35 \mu \mathrm{mol} / \mathrm{l})$, thyroxine-binding capacity of thyroxine-binding prealbumin (TBPA $A_{\text {cap }}, 1 \cdot 4-5 \cdot 0$ $\mu \mathrm{mol} / \mathrm{l}),{ }^{14}$ and urinary daily excretion of hydroxyproline (HOP, ${ }^{15}$ age-dependent reference values). Red cell glucose-6-phosphate dehydrogenase (G-6-PD, 1300-2400 IU/1) was determined at the Finnish Red Cross laboratory using standard method. The thyrotropin-releasing hormone (TRH) stimulation test was carried out by giving $7 \mu \mathrm{g} / \mathrm{kg}$ synthetic TRH IV (Novo Industri A/S, Denmark) and drawing blood samples for TSH determination before, and 20,60, and 120 minutes after the injection. In our laboratory the TSH response to TRH is considered normal when the difference between the basal and maximal TSH values $(\triangle \mathrm{TSH})$ is $3-30 \mathrm{mU} / 1$.

Nuclear binding of $\mathrm{T} 3$ in lymphocytes was studied using an in vitro method. ${ }^{10}$ Intact lymphocytes were isolated from venous blood and incubated in a medium with incremental concentrations of labelled T3. Equilibrium was achieved after 2 hours' incubation whereupon the nuclei were isolated and analysed for their T3 and DNA contents. The free T3 concentration was calculated from the known specific radioactivity of labelled hormone added. These data were analysed using Scatchard's method for estimating the equilibrium affinity constant $\left(\mathrm{K}_{\mathrm{a}}\right)$ and the specific maximal binding capacity (MBC). We had previously studied a population of 15 healthy adults, ${ }^{10}$ but as our patient was 9 years old, three children of about the same age were investigated for control purposes. These were three boys aged 11, 13, and 14; they did not have goitres or a history of thyroid disease. No sex differences in T3 receptor characteristics have been observed in this laboratory nor have they been reported from other laboratories.

\section{Case report}

History. The girl was born after 35 weeks' gestation, birthweight $2050 \mathrm{~g}$ and length $44 \mathrm{~cm}$. At one day she had tremors and slight respiratory distress and was admitted to hospital. The symptoms persisted for 8 days but no aetiological factor was found. She was discharged without symptoms at age 5 weeks.

The first child of the family had been born prematurely, birthweight $2070 \mathrm{~g}$, and died of respiratory distress at age 2 days. There is no family history of thyroid disease.

The patient's development was somewhat retarded, as she did not begin to walk and speak until age 18 months, but the parents considered her healthy. At the age of 1.4 years she was examined because of scaphocephalic skull shape and exophthalmos. Skull $x$-ray showed open sutures. Routine haematological tests were normal. Serum PBI was high, $1 \cdot 16 \mu \mathrm{mol} / 1(14 \cdot 7 \mu \mathrm{g} / 100 \mathrm{ml})$, but at the time this did not elicit further investigation. A year later PBI was $1.05 \mu \mathrm{mol} / 1(13.3 \mu \mathrm{g} / 100 \mathrm{ml})$. Hyperthyroidism was now suspected and she was admitted.

On examination, aged 2.9 years, the child was lively and alert and had slight finger tremor. Her height, $88 \mathrm{~cm}$, was $-1.8 \mathrm{SD}$ and her weight, $10 \cdot 1 \mathrm{~kg}$, was $-2.0 \mathrm{SD}$ from the median. She had a scaphocephalic head with frontal bossing, exophthalmos, and lid retraction, but no orbital or lid oedema (Fig. 1a, b). The thyroid was moderately enlarged with estimated weight $25 \mathrm{~g}$. Its consistency was soft and there were no palpable nodules. A systolic murmur was heard over the left sternal border, BP was $145 / 70 \mathrm{mmHg}$. Pulse rate was $88-128$. The chest was somewhat asymmetrical due to prominence of the left side with weak pectoral muscles, and she had winged scapulae. The 4th metacarpals were short and the toes were anomalous (Fig. 2). A skeletal $x$-ray showed the bone age to be 3 years and no epiphyseal abnormalities. Hearing, vision, and eye grounds were normal. Karyotype was $46 \mathrm{XX}$. Psychometry at the age of 8 gave an IQ of 96 (Wechsler Intelligence Scale for Children, verbal 99 


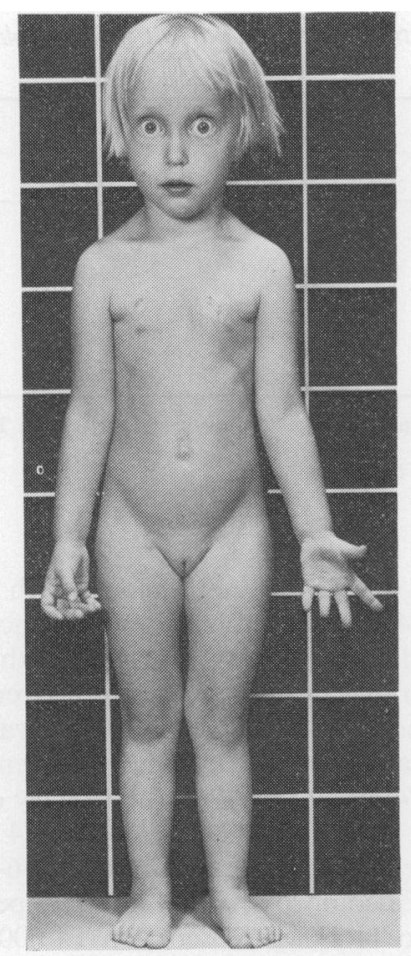

(a)

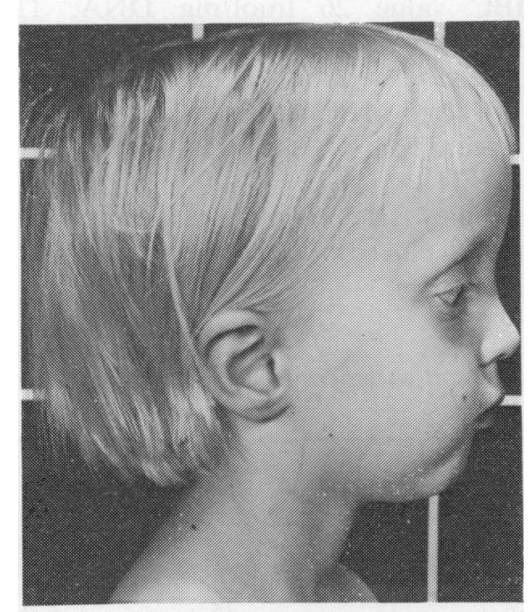

(b)

Fig. 1(a) The patient at age 2.9 years; note exophthalmos. (b) Note the small goitre, and scaphocephaly

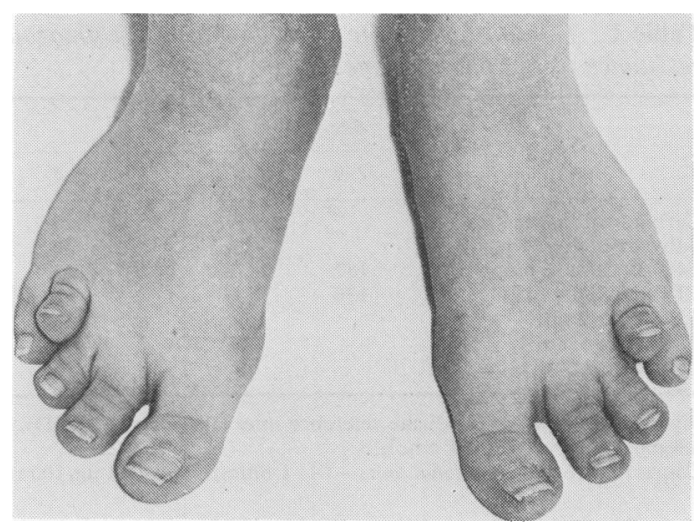

Fig. 2 Anomalies of the fourth toes.

and performance 94). Her school achievement has been below that of the other two children in the family.

Serum PBI was $1 \cdot 21 \mu \mathrm{mol} / 1(15 \cdot 3 \mu \mathrm{g} / 100 \mathrm{ml})$, T4CPB $187 \mathrm{nmol} / 1(14 \cdot 5 \mu \mathrm{g} / 100 \mathrm{ml})$, FT4 136 $\mathrm{pmol} / 1(10.6 \mathrm{ng} / 100 \mathrm{ml})$, urinary excretion of HOP $0.30 \mathrm{mmol} / 24 \mathrm{~h}(39 \mathrm{mg} / 24 \mathrm{~h})$, normal value at age 3 years $0 \cdot 15-0.35 \mathrm{mmol} / 24 \mathrm{~h}(20-46 \mathrm{mg} / 24 \mathrm{~h})$, and thyroidal $24 \mathrm{~h}$ uptake of radioiodine $26 \cdot 8 \%$ (reference interval $16-41 \%$ ). There was no LATS activity, and no circulating antibodies to thyroglobulin or microsomes. Despite the normal urinary excretion of HOP and normal thyroidal radioiodine uptake, the diagnosis of hyperthyroidism was made because of the goitre, the eye signs, and the mild tremor in combination with the high thyroid hormone concentrations. Treatment was started with a 20-mg per day dose of carbimazole. Four months later, when serum T4CPB was $50 \mathrm{nmol} / \mathrm{l}(3.9$ $\mu \mathrm{g} / 100 \mathrm{ml}$ ), thyroxine was added, starting with $55 \mu \mathrm{g}$ per day and increasing the dose to $110 \mu \mathrm{g}$ within three months. The laboratory data during treatment are presented in Table 1. It wäs difficult to evaluate the patient's clinical state because she was shy and frightened during the visits to the outpatient department. The parents' reports were more in keeping with euthyroidism than hyperthyroidism throughout the period of treatment. After 3.6 years of treatment serum $\mathrm{T} 3$ was raised although serum T4CPB had fallen to normal. When the carbimazole dose was reduced to $10 \mathrm{mg}$ per day after $4 \cdot 2$ years of treatment, T4CPB again rose to a thyrotoxic level and treatment with thyroxine was stopped. During treatment the thyroid size increased to approximately twice its initial size and serum TSH was found to be very high $(80 \mathrm{mU} / \mathrm{l})$. When the carbimazole dose was reduced, serum TSH also decreased. Carbimazole medication was then stopped and the patient was referred to an endocrinologist: 
Table 1 Thyroid function tests made during carbimazole and thyroxine treatment in a patient with peripheral resistance to thyroid hormones

\begin{tabular}{|c|c|c|c|c|c|c|c|c|}
\hline & \multicolumn{8}{|c|}{ Age (years) } \\
\hline & 2.9 & $3 \cdot 1$ & $3 \cdot 4$ & $4 \cdot 2$ & $5 \cdot 3$ & $6 \cdot 5$ & $7 \cdot 1$ & $7 \cdot 4$ \\
\hline $\begin{array}{l}\text { Carbimazole } \mathrm{mg} / 24 \mathrm{~h} \\
\text { L-thyroxine } \mu \mathrm{g} / 24 \mathrm{~h} \\
\text { T4CPB }(50-136 \mathrm{nmol} / \mathrm{l}) \\
\text { FT4 }(30-85 \mathrm{pmol} / \mathrm{l}) \\
\text { T3 }(1 \cdot 2-2 \cdot 9 \mathrm{nmol} / \mathrm{l}) \\
\text { TSH }(1 \cdot 6-6 \cdot 9 \mathrm{mU} / 1) \\
\text { TRH test: }(\triangle \mathrm{TSH} 3-30 \mathrm{mU} / 1)\end{array}$ & $\begin{array}{l}187 \\
136\end{array}$ & $\begin{array}{l}20 \\
50\end{array}$ & $\begin{array}{r}20 \\
110 \\
142\end{array}$ & $\begin{array}{r}10 \\
110 \\
194\end{array}$ & $\begin{array}{r}15 \\
111\end{array}$ & $\begin{array}{l}15 \\
83 \\
4 \cdot 0 \\
43\end{array}$ & $\begin{array}{c}10 \\
204^{*}\end{array}$ & $\begin{array}{r}192^{*} \\
199 \dagger \\
5 \cdot 5 \\
5 \cdot 4 \\
16 \cdot 2\end{array}$ \\
\hline
\end{tabular}

Figures in parentheses indicate reference intervals (mean \pm 2 SD). *T4RIA reference interval 60-160 nmol/1. †FT4 based on T4RIA reference interval 36-107 pmol/1.

Conversion: SI to traditional units-T4: $1 \mathrm{nmol} / 1 \approx 0.078 \mu \mathrm{g} / 100 \mathrm{ml} ; \mathrm{T} 3: 1 \mathrm{nmol} / 1 \approx 65 \mathrm{ng} / 100 \mathrm{ml}$.

After discontinuing therapy for the suspected hyperthyroidism, the following laboratory investigations were performed. Binding capacities of thyroid hormone transport proteins in serum were determined twice. TBG $_{\text {cap }}$ was 0.29 and 0.29 $\mu \mathrm{mol} / \mathrm{l}$, and $\mathrm{TBPA}_{\text {cap }}$ was 1.9 and $2.5 \mu \mathrm{mol} / 1$. Urinary excretion of HOP determined at the age of 8.2 years was $0.60 \mathrm{mmol} / 24 \mathrm{~h}(79 \mathrm{mg} / 24 \mathrm{~h})$, - that is normal for her age $(0 \cdot 30-0 \cdot 65 \mathrm{mmol} / 24 \mathrm{~h})$. Normal red cell G-6-PD activity was found (2440 IU/l). Because of her vegetative lability the urinary excretion of adrenaline and noradrenaline was measured; the result, $0.14 \mu \mathrm{mol} / 1$, is normal for her age. The adequacy of all urinary collections was confirmed by determining the creatinine content of the urine.

The pituitary-thyroid interaction was studied using the T3-suppression test 7 weeks after stopping carbimazole therapy. Treatment with a dose of $20 \mu \mathrm{g}$ T3 every 6 hours for 7 days suppressed the thyroidal $24 \mathrm{~h}$ radioiodine uptake only from 66 to $62 \%$. Basal serum TSH decreased from 5.4 to $4.5 \mathrm{mU} / 1$ and the TSH response to TRH fell from $16 \cdot 2$ to $14.8 \mathrm{mU} / 1$ ( $\triangle$ TSH). Serum T4RIA decreased from 179 to $154 \mathrm{nmol} / 1(13.9$ to $11.9 \mu \mathrm{g} / 100 \mathrm{ml})$.
Treatment with thyroxine. Therapy with incremental doses of T4 was started in order to reduce the size of the thyroid and to test the tolerance of the peripheral tissues (for the latter purpose the parents' consent was obtained). The size of the thyroid was normal by palpation at the end of treatment. When the patient received T4 $400 \mu \mathrm{g}$ per day the urinary excretion of HOP was $0.52 \mathrm{mmol} / 24 \mathrm{~h}(68 \mathrm{mg} / 24 \mathrm{~h})$-that is normal for her age, and the red cell G-6-PD activity (1710 U/l) also normal. On T4 $500 \mu \mathrm{g}$ per day, TSH response to TRH was absent; on T4 $600 \mu \mathrm{g}$ per day slight symptoms and signs of hyperthyroidism were observed (Table 2).

Lymphocyte studies. A single set of saturable T3 binding sites in lymphocyte nuclei was found. The estimated $\mathrm{K}_{\mathrm{a}}$ value was $3.5 \times 10^{10} \mathrm{l} / \mathrm{mol}$ and the MBC value $26 \mathrm{fmol} / \mathrm{mg}$ DNA. The three euthyroid control subjects of a similar age had $\mathrm{K}_{\mathrm{a}}$ values ranging from 2.3 to $3.8 \times 10^{10} \mathrm{l} / \mathrm{mol}$ (mean 3.1) and MBC values from 44 to $66 \mathrm{fmol} / \mathrm{mg}$ DNA (mean 56).

Family studies. The parents and the siblings (an elder sister and an elder brother) were clinically euthyroid

Table 2 Thyroid function tests made during thyroxine treatment in a patient with peripheral resistance to thyroid hormones

\begin{tabular}{|c|c|c|c|c|c|c|c|c|}
\hline \multicolumn{2}{|l|}{ Thyroxine } & \multirow{2}{*}{$\begin{array}{l}\text { T4RIA } \\
\left(60-160^{*}\right. \\
\text { nmol/l) }\end{array}$} & \multirow{2}{*}{$\begin{array}{l}F T 4 \\
(36-107 \\
p m o l / l)\end{array}$} & \multirow{2}{*}{$\begin{array}{l}T 3 \\
(1 \cdot 2-2 \cdot 9 \\
n m o l / l)\end{array}$} & \multicolumn{4}{|c|}{$\begin{array}{l}\text { TRH test } \\
(\Delta T S H \text { 3-30 mU/L) }\end{array}$} \\
\hline $\begin{array}{l}\text { Dose } \\
(\mu g / 24 h)\end{array}$ & $\begin{array}{l}\text { Duration } \\
\text { (weeks) }\end{array}$ & & & & 0 & $20 \min$ & $60 \mathrm{~min}$ & $120 \mathrm{~min}$ \\
\hline $\begin{array}{l}\text { None } \\
100 \\
200 \\
300 \\
400 \\
500\end{array}$ & $\begin{array}{l}4 \\
4 \\
4 \\
4 \\
5\end{array}$ & $\begin{array}{l}179(204) \dagger \\
208\end{array}$ & $211(303) \dagger$ & $5.8(11 \cdot 5) \dagger$ & $\begin{array}{r}5.4 \\
<1.6 \\
3.4 \\
1.8 \\
<1.6 \\
<1.6\end{array}$ & $\begin{array}{c}17 \\
17 \\
24 \\
24 \\
5 \cdot 0 \\
2.4\end{array}$ & $\begin{array}{c}22 \\
15 \\
17 \\
9 \cdot 1 \\
4 \cdot 5 \\
2 \cdot 0\end{array}$ & $\begin{array}{l}20 \\
6 \cdot 0 \\
9 \cdot 5 \\
5 \cdot 2 \\
2 \cdot 2\end{array}$ \\
\hline
\end{tabular}

* Reference interval (mean \pm 2 SD), $† 120$ min after injection of TRH. 
and nongoitrous. Their serum thyroid hormone concentrations were normal and they had no circulating thyroid antibodies. There was no history of consanguinity.

\section{Discussion}

When seen at about age 3 years the girl was considered to be suffering from slight hyperthyroidism. The diagnosis was based on goitre, exophthalmos, lid retraction, tachycardia, finger tremor, poor weight gain, and high serum thyroid hormone concentrations. In retrospect, the exophthalmos was probably caused by the scaphocephalic skull and the lid retraction by excess sympathetic tone, which also explains the tachycardia and finger tremor. The initial diagnosis of hyperthyroid Graves's disease must therefore be rejected, a conclusion supported by later clinical and laboratory findings.

Some possible explanations for the peculiar findings in this case deserve consideration. Neoplastic production of TSH can be excluded in the light of the long history, the normal skull $x$-ray, and the normal eye grounds. The binding capacities of TBG and TBPA were normal and the raised thyroid hormone levels cannot therefore be due to increased binding to these transport proteins. Inappropriate T4 and T3 radioimmunoassay levels are sometimes due to circulating thyroid hormone autoantibodies present in various thyroid conditions, particularly in chronic lymphocytic thyroiditis. ${ }^{16}{ }^{20}$ This possibility was ruled out in our patient by demonstrating similar T4 concentrations with both the T4CPB ethanol extraction method and direct T4RIA. Neither was the level of nonspecific binding unusually high in the T3RIA.

The combination of raised thyroid hormone concentrations and clinical euthyroidism indicates a peripheral refractoriness to the action of these hormones. The lack of response of hydroxyproline excretion and red cell G-6-PD activity to large amounts of thyroxine demonstrated the refractoriness of connective and erythropoetic tissues. This peripheral insensitivity also includes the anterior pituitary, since serum TSH was normal despite the increased thyroid hormone level. The pronounced insensitivity of the pituitary was apparent when T3 in a dose of $80 \mu \mathrm{g}$ per day for one week resulted in only a $17 \%$ decrease in serum $\mathrm{TSH}$, and a concomitant decrease in the thyroidal radioiodine uptake of only $6 \%$. With thyroxine the TSH secretion was suppressible only after the administration of $400 \mu \mathrm{g}$ daily. Complete suppression of TSH is normally achieved with less than $250 \mu \mathrm{g}$ thyroxine per day, even in adults. In order to elicit very slight symptoms of hyperthyroidism, as much as $600 \mu \mathrm{g}$ thyroxine per day had to be given-much more than is needed to induce factitious hyperthyroidism even in adults. During treatment with carbimazole the functional integrity of the pituitary-thyroid negative feed-back system was demonstrated; when the serum thyroid hormone levels decreased, the secretion of TSH was stimulated and the TSH response to TRH exaggerated. As a consequence of the increase in TSH the thyroid was further enlarged.

Our patient obviously belongs to the group of patients with various degrees of peripheral resistance to thyroid hormones, but her clinical appearance is not similar in all respects to that of the sporadic and familial cases previously described. She did not have loss of hearing or delayed bone maturation and therefore differs from the clinically much more severe form of familial peripheral resistance described by Refetoff et al. ${ }^{1}$ She bears a closer resemblance to the sporadic cases reported by Lamberg ${ }^{4}$ and Bode et al. ${ }^{5}$ but differs from these because of skeletal changes. Weight gain was modest in our patient but the growth failure as reported by Schneider et al. ${ }^{6}$ in a 13-year-old boy with peripheral resistance was absent. The relationship between the bone abnormalities seen in our patient and the peripheral resistance to thyroid hormones demonstrable also in connective tissue remains obscure.

This patient had one set of saturable nuclear binding sites for T3 in lymphocytes similar to our findings in normal adults. ${ }^{10}$ The estimated affinity constant also equalled that of healthy subjects. Interestingly enough, the number of receptor sites was less than half the mean number observed in three age-matched controls. The binding characteristics of these control children did not vary significantly from those of the adults, although it cannot be ruled out that lymphocyte receptors in younger children might have different binding properties. Studies on lymphocytes from newborn rats indicate such a possibility. ${ }^{17}$ When the T3 binding data on this patient are compared with those on control subjects available ( 3 children and 15 adults), the probability of $\mathrm{MBC} 26 \mathrm{fmol} / \mathrm{mg}$ DNA being abnormally low is at the level of 0.05 $>\mathrm{P}>0.01$. This is in conformity with the relatively low T3 binding capacity observed also in lymphocyte nuclei from three members of a family with very slight forms of peripheral resistance syndrome. ${ }^{10}$

The possibility that the decreased apparent binding capacity could result from a higher degree of saturation of nuclear receptors with endogenous hormone due to the raised serum T3 level must be recognised. This is very unlikely, however, since two independent studies demonstrated that the binding 
capacity was normal in hyperthyroid patients, many with substantially higher serum $\mathrm{T} 3$ concentrations than the subjects with peripheral resistance. ${ }^{10} 18$

The possibility that circulating lymphocytes might not correctly reflect the receptor status of other cells in patients with peripheral resistance also needs consideration. In a patient with a hereditary form of this syndrome, high affinity receptors were absent from lymphocytes whereas such receptors were detected in fibroblasts. ${ }^{9}$ This finding is particularly surprising as this patient had severe skeletal abnormalities but no signs of lymphocytic dysfunction.

Since a sporadic case of peripheral resistance syndrome $^{4}$ with a normal concentration of T3 receptors in lymphocytes ${ }^{19}$ has also been observed, it seems as if there could be different underlying defects in these syndromes. Since no conclusive evidence for the existence of a nuclear receptor defect in the various peripheral resistance syndromes so far studied has been provided, the location of the biochemical defect might be at a point in the mechanism of thyroid hormone action subsequent to binding at the nuclear receptor.

We are grateful for grants for this study from the Nordic Insulin Fund, Copenhagen, Denmark.

\section{References}

1 Refetoff S, DeGroot L J, Benard B, DeWind L T. Studies of a sibship with apparent hereditary resistance to the intracellular action of thyroid hormone. Metabolism 1972; 21 : 723-56.

- Agerbaek H. Congenital goiter presumably resulting from tissue resistance to thyroid hormones (abstract). European Thyroid Association Fifth Annual Meeting. Isr J Med Sci $1972 ; 8$ : 1859-60.

- Lamberg B-A, Rosengård S, Liewendahl K, Saarinen P, Evered D C. Familial partial peripheral resistance to thyroid hormones. Acta Endocrinol (Kbh) 1978; 87: 303-12.

- Lamberg B-A. Congenital euthyroid goitre and partial peripheral resistance to thyroid hormones. Lancet 1973; 1: 854-7.

- Bode H H, Danon M, Weintraub B D, Maloof F, Crawford J D. Partial target organ resistance to thyroid hormone. J Clin Invest 1973; 52: 776-82.

- Schneider G, Keiser H R, Bardin C W. Peripheral resistance to thyroxine: a cause of short stature in a boy without goitre. Clin Endocrinol 1975; 4: 111-8.

- Elewaut A, Mussche M, Vermeulen A. Familial partial target organ resistance to thyroid hormones. J Clin Endocrinol Metab 1976; 43: 575-81.

- Gershengorn M C, Weintraub B D. Thyrotropininduced hyperthyroidism caused by selective pituitary resistance to thyroid hormone. $J$ Clin Invest 1975; 56: 633-42.

- Bernal J, Refetoff S, DeGroot L J. Abnormalities of triiodothyronine binding to lymphocyte and fibroblast nuclei from a patient with peripheral tissue resistance to thyroid hormone action. J Clin Endocrinol Metab 1978; 47: 1266-72.

10 Liewendahl K, Rosengård S, Lamberg B-A. Nuclear binding of triiodothyronine and thyroxine in lymphocytes from subjects with hyperthyroidism, hypothyroidism, and peripheral resistance to thyroid hormones. Clin Chim Acta 1978; 83: 41-8.

11 Liewendahl K, Helenius T. Comparison of free thyroxine indices and 'corrected' thyroxine tests. Clin Chim Acta 1975; 64: 263-72.

12 Gordin A, Saarinen P. Methodological study of the radioimmunoassay of human thyrotrophin. Acta Endocrinol (Kbh) 1972; 71: 24-36.

13 Lamberg B-A, Gordin A, Viherkoski M, Kvist G. Longacting thyroid stimulator (LATS) in toxic nodular goitre, toxic adenoma, and Graves' disease. Acta Endocrinol (Kbh) 1969; 62: 199-209.

14 Di Giulio W, Michalak Z, Weinhold P A, Hamilton J R, Thoma G E. Use of agar gel electrophoresis and autoradiography to measure thyroxine-binding protein capacities. J Lab Clin Med 1964; 64: 349-54.

15 Kívirikko K I, Laitinen O, Prockop D J. Modifications of a specific assay for hydroxyproline in urine. Anal Biochem 1967; 19: 249-55.

16 Ginsberg J, Segal D, Ehrlich R M, Walfish P G. Inappropriate triiodothyronine (T3) and thyroxine (T4) radioimmunoassay levels secondary to circulating thyroid hormone autoantibodies. Clin Endocrinol 1978; 8: 133-9.

17 Csaba G, Sudár F, Dobozy O. Triiodothyronine receptors in lymphocytes of newborn and adult rats. Horm Metab Res 1977; 9: 499-501.

18 Lemarchand-Béraud T, Holm A-C, Scazziga B-R. Triiodothyronine and thyroxine nuclear receptors in lymphocytes from normal, hyper- and hypothyroid subjects. Acta Endocrinol (Kbh) 1977; 85: 44-54.

19 Liewendahl K. Triiodothyronine binding to lymphocytes from euthyroid subjects and a patient with peripheral resistance to thyroid hormone. Acta Endocrinol (Kbh) 1976; 83: 64-70.

20 Staeheli V, Vallotton M B, Burger A. Detection of human anti-thyroxine and anti-triiodothyronine antibodies in different thyroid conditions. J Clin Endocrinol Metab $1975 ; 41$ : 669-75.

21 Helenius T, Liewendahl K. Abnormal thyroid function tests in severe non-thyroidal illness: diagnosis and pathophysiologic aspects. Scand J Clin Lab Invest 1979; 39: 389-97.

Correspondence to Dr J Mäenpää, Aurora Hospital, Nordenskiöldinkatu 20, SF-00250 Helsinki 25, Finland.

Received 27 February 1979 